\title{
Introduction to the Special Issue on 3D Methodologies in Mediterranean Archaeology
}

\author{
MATTHEW F. NOTARIAN, Hiram College, OH, USA
}

\begin{abstract}
This issue brings together several papers originally presented at the 2019 annual meeting of the Archaeological Institute of America in a panel entitled, "Three-Dimensional Archaeology Comes of Age." This collection takes stock of a decade's worth of groundbreaking transformation in archaeological practices with a focus on the ancient Mediterranean. Over this time, a subtle transition has occurred in which contentious debates over the value and practicality of 3D tools, such as photogrammetry, 3D scanning, 3D reconstruction, and virtual reality (VR), have given way to an emergent consensus that these constitute a new and important class of recording and heuristic instruments. Rather than seek to cover this fundamental shift in a comprehensive matter, this issue presents a characteristic cross-section of current archaeological research based in three-dimensional computational methodologies. The content cuts across some 3000 years of Mediterranean archaeology, from the Aegean Bronze Age to the later Roman Empire, underlining the discipline-wide impact of this methodological revolution. It seeks to shed light on how digital tools are transforming not just the ways we record data, but the very questions archaeologists ask of this information and how this will shape methodological and analytical trends in the next decade and beyond.
\end{abstract}

Key words:

Digital archaeology, field practices, photogrammetry, 3D recording, archaeological illustration, 3D reconstruction, virtual reality.

SDH Reference:

Matthew F. Notarian. 2020. Introduction the Special Issue on 3D Methodologies in Mediterranean Archaeology. SDH, 4, 2, 75-77.

https://doi.org/10.14434/sdh.v4i2.32095

\section{INTRODUCTION}

This issue brings together several papers originally presented at a colloquium of the 2019 annual meeting of the Archaeological Institute of America in San Diego, CA, entitled, "Three-Dimensional Archaeology Comes of Age." The goal of that panel was to take stock of about a decade's worth of groundbreaking transformation in archaeological practices with a focus on the ancient Mediterranean.

Over the course of the previous decade, a subtle transition has occurred in which contentious debates over the value and practicality of 3D tools, such as photogrammetry, 3D scanning, 3D recording, and

Author's address: Matthew Notarian, Department of Modern Languages and Classics, Hiram College, P.O. Box 67, Hiram, OH, 44234, USA; email: mnotarian@gmail.com

(c) [2020] by the authors; licensee Studies in Digital Heritage, IU, Bloomington (IN), USA. This article is an open access article distributed under the terms and conditions of the Creative Commons Attribution License (CC BY-NC) 
virtual reality (VR), have given way to an emergent consensus that these constitute a new and important class of recording and heuristic instruments [e.g. Olson and Caraher 2015; Averett, Gordon and Counts 2016; Koenig et al. 2017; Landeschi 2019]. Furthermore, technological improvements in software and hardware continue to drive costs downwards, leading to their adoption by an almost exponentially increasing number of projects each year. Similar advances in unmanned aerial vehicle (UAV) technology have also made aerial photography commonplace. Open-source and economically priced 3D modeling software let even non-specialists create sophisticated 3D reconstructions of ancient architecture, artifacts, and art, opening new avenues of both qualitative and quantitative data analysis. In short, 3D approaches to archaeological recording, analysis, reconstruction, and publishing have shifted from specialist niches to mainstream methodology. At the same time, experts have continued to push boundaries with groundbreaking forms of documentation and inquiry, driving innovation at a broader level. These rapid and exciting changes led Roosevelt et. al [2015] to boldly revise the adage "archaeology is destruction" to "archaeology is digitization" in an already seminal article. Nevertheless, archaeological epistemology is still catching up to this new three-dimensional reality, often compacting 3D data down to theoretical questions grounded in more familiar 2D thinking. The articles collected in this issue each explore how new technologies are pushing research closer to a true "3D turn" as envisioned by Campana [2014].

Given the scope of the digital revolution in archaeology, this selection of papers cannot possibly cover the fundamental shift in a comprehensive manner (see Garstki [2020] for a recent overview). It instead represents a characteristic cross-section of current archaeological research based in threedimensional computational methodologies and adds to a growing body of research on this possible paradigm shifting moment in archaeological thought. Anderson and Notarian each offer reflective examinations of the impacts, benefits, and challenges of photogrammetry in recording excavation from the perspective of early and late adopters, respectively. Sapirstein's article contributes an important study to the ongoing debate over the consequences of a shift from measured hand drawing to computer-based techniques in fieldwork. Finally, the contributions by Clinton and Fredrick and Vennarucci offer early data on novel approaches to understanding human navigation of architectural spaces by analyzing crowd sourced data from 3D reconstructions inside gaming environments.

The original AIA session also included presentations by two authors not represented in this collection. Justin Leidwanger spoke about measuring and quantifying the standardization of late antique transport amphorae using photogrammetry and structured light-scanning. Matthew Brennan presented the use of VR as a tool for researchers to interact with archaeological stratigraphy in an immersive environment far from the field. Philip Sapirstein's presentation differed from the paper published here, instead examining the challenges of disseminating resource-intensive data from a highly accurate photogrammetric survey of the Heraion at Olympia.

As a whole, the content of this issue cuts across some 3,000 years of Mediterranean archaeology, from the Aegean Bronze Age to the later Roman Empire, underlining the discipline-wide impact of this methodological revolution. It seeks to shed light on how digital tools are transforming not just the ways we record data, but the very questions archaeologists ask of this information and how this will shape methodological and analytical trends in the next decade and beyond.

Studies in Digital Heritage, Vol. 4, No. 2, Publication date: December 2020 


\section{ACKNOWLEDGEMENTS}

I give my sincere thanks to the participants of the original AIA colloquium and especially the authors whose contributions herein provide timely and valuable insight into this exciting moment in archaeological research. David Fredrick, in particular, offered early encouragement and suggestions for conference participants. Matthew Brennan was instrumental in the early efforts to bring this issue to publication.

\section{REFERENCES}

Erin Walcek Averett, Jody Gordon, and Derek Counts, eds. Mobilizing the Past: Recent Approaches to Archaeological Fieldwork in a Digital Age. Grand Forks: The Digital Press at the University of North Dakota.

Stefano Campana. 2014. 3D Modeling in Archaeology and Cultural Heritage-Theory and Best Practice. In Fabio Remondino and Stefano Campana, eds. 3D Recording and Modelling in Archaeology and Cultural Heritage. Oxford: BAR International Series 2598, 7-12

Kevin Garstki. 2020. Digital Innovations in European Archaeology. Elements in the Archaeology of Europe. Cambridge: Cambridge University Press. https://doi.org/10.1017/9781108881425

Charles W. Koenig, Mark D. Willis, Stephen L. Black. 2017. Beyond the Square Hole: Application of Structure from Motion Photogrammetry to Archaeological Excavation. Advances in Archaeological Practice 5, 1 (2017), 54-70. https://doi.org/10.1017/aap.2016.8

Giacomo Landeschi. 2019. Rethinking GIS, three-dimensionality and space perception in archaeology. World Archaeology 51,1 (2019), 17-32. https://doi.org/10.1080/00438243.2018.1463171

Brandon R. Olson and William R. Caraher eds. 2015. Visions of Substance: 3D Imaging in Mediterranean Archaeology. Grand Forks: The Digital Press at the University of North Dakota.

Christopher H. Roosevelt, Peter Cobb, Emanuel Moss, Brandon R. Olson, and Sinan Ünlüsoy. 2015. Excavation is Destruction Digitization: Advances in Archaeological Practice. Journal of Field Archaeology 40 (2015), 325-346. http://dx.doi.org/10.1179/2042458215Y.0000000004

Received June 2020; revised December 2020; accepted December 2020. 